\title{
Les Munebih du Yémen perçus par leurs voisins : description d'une société par le corps et sa parure
}

Andre Gingrich

\section{(2) OpenEdition}

1 Journals

Édition électronique

URL : https://journals.openedition.org/tc/790

DOI : $10.4000 /$ tc. 790

ISSN : 1952-420X

Éditeur

Éditions de l'EHESS

\section{Édition imprimée}

Date de publication : 1 février 1990

ISSN : 0248-6016

\section{Référence électronique}

Andre Gingrich, «Les Munebih du Yémen perçus par leurs voisins : description d'une société par le corps et sa parure », Techniques \& Culture [En ligne], 13 | 1990, mis en ligne le 16 janvier 2006, consulté le 29 septembre 2022. URL : http://journals.openedition.org/tc/790 ; DOl : https://doi.org/10.4000/tc. 790

Ce document a été généré automatiquement le 29 septembre 2022.

Tous droits réservés 
Les Munebih du Yémen perçus par leurs voisins : description d'une société par le corps et sa parure

Andre Gingrich 